\title{
THE
}

\section{Educational Perspectives and Teaching Styles of Faculty Who Lead International Service-Learning Experiences}

Jennifer G. Audette

University of Rhode Island, jaudette@uri.edu

Susan E. Roush

University of Rhode Island, roush@uri.edu

Follow this and additional works at: https://digitalcommons.uri.edu/pt_facpubs

\section{The University of Rhode Island Faculty have made this article openly available.}

Please let us know how Open Access to this research benefits you.

This is a pre-publication author manuscript of the final, published article.

Terms of Use

This article is made available under the terms and conditions applicable towards Open Access

Policy Articles, as set forth in our Terms of Use.

\section{Citation/Publisher Attribution}

Audette, J. G., \& Roush, S. E. (2013). Educational perspectives and teaching styles of faculty who lead international service-learning experiences. J. Phys. Ther. Educ., 27(2), 65-73.

Available at: https://journals.Iww.com/jopte/Abstract/2013/01000/

Educational_Perspectives_and_Teaching_Styles_of.14.aspx 
Educational Perspectives and Teaching Styles of Faculty Who Lead International Service-Learning Experiences

Jennifer G. Audette, PT, PhD

Susan E. Roush, PT, PhD

Biographical Data:

Jennifer Audette is a Clinical Assistant Professor in the Physical Therapy Department, Doctor of Physical Therapy Program, at the University of Rhode Island, 25 West Independence Way, Kingston, RI 12881 (jaudette@ mail.uri.edu). Please address all correspondence to Jennifer Audette.

Susan E. Roush is a Professor in the Physical Therapy Department, Doctor of Physical Therapy Program, at the University of Rhode Island, 25 West Independence Way, Kingston, RI 12881 Key words: Physical Therapy Faculty, International Service-Learning, Teaching Style 


\begin{abstract}
Background and Purpose: Many physical therapy educational programs are adding international service-learning (ISL) opportunities to their curricula as a way to address the increasingly global nature of the profession. There is a paucity of physical therapy literature addressing ISL, with a particular deficiency related to ISL faculty. The purpose of this study was to describe faculty demographics, teaching styles, and educational perspectives, and to compare faculty who did and did not lead ISL experiences with physical therapy students.

Subjects: Two hundred five physical therapy faculty; $23 \%$ of whom led ISL.

Methods: Subjects were recruited through two professional listservs and data were gathered via a commercial web-based service. Faculty with and without ISL experience were compared on demographic variables, Teaching Style, and Educational Perspective. Measurement tools included standard demographic inquires, the Grasha and Riechmann-Hruska Teaching Style Survey, and a researcher-developed Educational Perspective questionnaire. Logistic regression was used to explore characteristics predictive of participation in ISL.

Results: Subjects' most common teaching style was Personal Model / Formal Authority / Delegator and a Professional focus was the most commonly identified educational perspective. Familiarity with key educational authors was limited. There was no relationship between ISL involvement and teaching style, but a relationship was identified between ISL involvement and the Critical perspective. The factors in this study were not predictive of ISL participation.

Discussion and Conclusion: In general, ISL faculty did not differ from their colleagues who did not have ISL experience. Study findings, however, can inform, and provide rationale and support for existing and future ISL programs. This study also provides a context for encouraging the discussion and exploration of faculty teaching styles and educational perspectives.
\end{abstract}




\section{Background and Purpose}

International service-learning (ISL) is popular throughout higher education, and many physical therapy educational programs are adding ISL opportunities to their curricula. ${ }^{1}$

Development of these ISL experiences aligns with student interest as well as the increasingly global nature of our profession. ${ }^{2}$ Globalization is influencing healthcare and physical therapists are likely to encounter marked diversity in any setting in which they practice. Indeed, the $21^{\text {st }}$ century has seen the profession of physical therapy taking a more global stance and positioning itself for enhanced international awareness and collaboration. ${ }^{3}$ Therefore, providing opportunities for physical therapy students to experience diversity and increase their cultural competence is critical. One way to address these issues in academic programs is to provide ISL opportunities, which may help to develop skills and attributes that enhance students' preparation for practice in this culturally diverse and global health arena.

Before exploring ISL further, differentiating it from service learning (SL) is appropriate. Seifer ${ }^{4(p 274)}$ defined SL as "structured learning experiences that combine community service, explicit learning objectives, preparation, and reflection." Service-learning conducted in international settings is referred to as ISL; ISL conceptually and pedagogically grew out of SL. There is a sizeable and growing body of SL literature; in contrast, there is a remarkably limited body of ISL literature. This study was conceptualized in the context of SL and ISL literature.

Many prominent educational theorists and researchers have explored important pedagogical issues associated with SL at the college level. Issues that have been explored include authenticity, ${ }^{4-7}$ higher order thinking, ${ }^{8-11}$ theoretical support, ${ }^{6,8}$ reflection, ${ }^{12-14}$ key features of campus-community partnerships, ${ }^{14-22}$ and student outcomes such as general impact, ${ }^{4,17-28}$ citizenship and service levels, ${ }^{29,30}$ and application of course content. ${ }^{30}$ There is a small body of 
physical therapy related SL literature. The primary foci of this work has been student outcomes, ${ }^{31,32}$ general impact, ${ }^{33}$ pedagogy and implementation, ${ }^{34-36}$ and professionalism factors. ${ }^{37}$ Typical physical therapy student SL objectives include improving clinical skills, reinforcing educational goals, encouraging a commitment to community service, improving civic awareness, and enhancing cross-cultural understanding. The opportunity to address additional objectives such as facilitation of cultural sensitivity and competence is presented when SL activities take place internationally.

No literature exists regarding why faculty become involved in ISL, although faculty involvement in SL has been explored. Hammond ${ }^{38}$ identified three predominant categories of motivators: personal, co-curricular, and curricular. The personal motivators include past involvement in service, affinity for service, endorsement of social change, desire to work with students outside the classroom, and an interest in helping those in need. Faculty co-curricular motivators include promotion of civic involvement, moral character development, and improved multicultural understanding in students. Curricular motivators include effective presentation of content material, encouragement of self-directed learning, professional training, and experiential application of content. Faculty have also used SL for the development of global citizenship and an understanding of common good, justice, equity, and fairness in students. ${ }^{39} \mathrm{O}$ 'Meara and Niehaus ${ }^{40}$ found faculty to be motivated to use SL because it: 1) creates opportunities to shape the civic and moral dispositions of students, 2) serves as a positive model for teaching and learning, 3) provides an opportunity for students' expression of personal identity, 4) can be an expression of institutional mission and values, and 5) fosters valuable community partnerships.

In contrast to the number of studies that have examined various aspects of faculty involvement in SL in other fields, ${ }^{4,28,38-48}$ there are no data on physical therapy faculty. In 
physical therapy, only student ISL outcomes ${ }^{49}$ and the prominence and development of ISL in physical therapy educational programs ${ }^{1,50}$ have been studied. Although these studies are seminal, specific faculty characteristics were beyond their scope.

Understanding faculty characteristics is important because the experience and educational perspective of SL faculty leaders can be a major influence on how SL experiences are conceptualized and brought to fruition. ${ }^{51}$ Faculty - particularly physical therapy faculty - may not be aware of existing literature that could support and inform SL-related practices and objectives. Indeed, it has only been since 1987 that the physical therapy profession has had a peer reviewed journal specific to the scholarship of teaching and learning. ${ }^{52}$ This limited history means that physical therapy faculty, including faculty who lead ISL experiences, may have developed as educators without strong pedagogical support. Teaching styles and pedagogical perspectives are two areas of educational literature that have direct application to many aspects of SL pedagogy. ${ }^{51}$ Understanding teaching styles and pedagogical perspectives allows faculty to broaden their understanding of what SL and ISL can do and the objectives that can potentially be achieved. Additionally, enhanced understanding of educational perspectives opens up a body of literature that can support, justify, and legitimize time and cost associated with SL and ISL experiences. Teaching Style

Many learning style inventories exist, but their counterpart, teaching style inventories are less common. Those that do exist ${ }^{53,54,55}$ are only minimally referenced in the literature or are not meant for use in higher education. The most appropriate and frequently referenced tool appears to be the Teaching Style Survey developed by Grasha and Riechmann-Hruska. ${ }^{56}$

Grasha and Riechmann-Hruska define teaching styles as a combination of qualities, needs, beliefs, and behaviors that are important in guiding and directing the way teachers 
teach. ${ }^{56-59}$ Their survey identifies five teaching style types: 1) expert, 2) formal authority, 3)

personal model, 4) facilitator, and 5) delegator. ${ }^{56-59}$ The five styles are described in Appendix A. No one style is more or less effective than another, but each style has advantages and disadvantages. Styles are not mutually exclusive and typically teachers possess and blend styles together. The authors refer to these blended styles as teaching style clusters. ${ }^{56-59}$

\section{Educational Perspective: Progressive, Critical, Professional}

The work of three scholars have particular relevance to SL and ISL experiences: the progressive perspective of John Dewey, ${ }^{60-64}$ the critical pedagogy perspective of Paolo Freire, ${ }^{65}$ and the professional perspective of Pamela Reynolds. ${ }^{37}$ These three perspectives are complementary, yet they serve as the foundation for diverse ways of thinking about and interacting with students, and developing courses and learning objectives.

John Dewey $(1859$ - 1952) is regarded as the father of progressive educational theory. The pedagogical implications of Dewey's work are seen in experiential learning curricula ${ }^{66}$ which was the forerunner of SL as pedagogy. The main features of a progressive theoretical frame are relevant to and provide a lens for exploration of SL and ISL topics. Those with a progressive perspective consider education a progressive process in which students are problemsolvers who will develop their own understanding and control over learning. They also believe that democratic procedures should be used in the classroom or learning environment. The provision of learning experiences that are meaningful and allow for solving challenges and problems in real-life situations and environments are critical and stimulate active thinking and problem-solving. The belief of progressivists is that context and structure should lead the student to discovery and learning. ${ }^{62-64,67,68}$ Additionally, progressivists stress the importance of social interaction, discourse, and conversation because these elements strengthen the link between 
cognitive and moral development. These educators draw on the individual talents and capabilities of students. Progressivists see reflecting on activities as an integral part of the learning process because it makes learning experiences personal and provides an opportunity for individual construction of meaning and autonomy.

The critical perspective has also greatly influenced educational thinking and practice. It is an educational movement that is intended to help students develop awareness and consciousness about issues such as social injustice, freedom, and authoritarianism. The primary originator of critical pedagogy is Paulo Freire (1921-1997). Freire ${ }^{65}$ rejected the notion proposed by other educators of his time, that students were empty vessels waiting to be filled by their teachers and preferred the idea of reciprocity between teachers and students. Freire was deeply interested in how education addressed issues of diversity and culture. ${ }^{65,69,70}$ Educators with a critical perspective tend to be guided by strong principles and passions ${ }^{70}$ and expect students to consider power relationships and think about how to take active measures to right social injustices. Educators who aspire to critical pedagogy pose problems with current world examples to raise social consciousness and elicit reaction to world events and challenge the status quo. Further, they provide students with learning opportunities that develop socially alert, responsive, and aware citizens. From this perspective, educators take an anthropological perspective and make use of the socioeconomic, racial, and cultural differences of the students.

While physical therapy educators may incorporate progressive and/or critical pedagogical ideas into their teaching, they also must function within the constraints of delivering a curriculum directly tied to accreditation standards that ultimately lead to licensure and practice as a physical therapist. Because of this, a third educational perspective must be considered, namely, a professional focus. Professional education focuses on learning skills and developing 
professional attributes that are needed in future employment settings. Educators with a professional perspective tend to be practical and focused on education as a means of producing clinically competent practitioners. They are driven by guidelines and standards set by professional organizations and/or accrediting bodies. In physical therapy, the American Physical Therapy Association (APTA) and the Commission on Accreditation of Physical Therapy Education (CAPTE) are such bodies.

Pamela Reynolds ${ }^{37}$ researched professional development as it relates to SL. She asserts that professional skills that are difficult to teach in a classroom setting can be addressed through well-integrated SL. Although Reynolds is not an educational theorist, her work illustrates the professional perspective as it relates to the education of physical therapists, educational outcomes in physical therapy, and connecting SL pedagogy to specific evaluative criteria necessary for the accreditation of educational programs, other professional standards, and clinical performance competencies. She argues that SL experiences should encourage students to focus on making practical contributions beyond their professional role and expanding their perception and understanding of health and illness, particularly for members of underserved populations.

Because progressive, critical, and professional perspectives all have potential relevance for SL, by extension they also relate to ISL. For example, progressive perspective educators may be drawn toward ISL for its potential to provide opportunities for students to actively experience real life, student-centered situations in which group dialogue and problem-solving are critical. Critical perspective educators may be intrigued by ISL for its potential to create learning situations in which students are transformed through active participation - side-by-side with a teacher - in opportunities that challenge the status quo and address current social justice issues 
and needs. Finally, educators with a professional perspective may be attracted to ISL because these opportunities put students in situations where they can develop competence and practice skills they have learned in the classroom.

Little is known about the teaching styles or theoretical perspectives of physical therapy faculty and how these characteristics might relate to ISL participation. Further, there is a paucity of information about physical therapy faculty who lead ISL experiences and how they compare to faculty who lack this experience. The primary purpose of this study, therefore, was to describe faculty 1) demographic variables including age, gender, degree, faculty position, years as a physical therapist, and years teaching, 2) teaching styles as defined by Grasha and RiechmannHruska, ${ }^{56}$ and 3 ) educational perspectives including progressive, critical, and professional perspectives. A secondary purpose was to compare these same variables in faculty who do and do not lead ISL. For this secondary purpose, the null hypothesis was assumed since the literature did not provide adequate support for either directional or research hypotheses.

\section{Methods}

\section{Instrument}

Four types of data were collected with a Faculty Survey: 1) Demographics, 2) Teaching experience - including ISL experience, 3) Teaching Style, and 4) Theoretical Perspective. The Faculty Survey was comprised of an existing teaching style tool ${ }^{56}$ and researcher-developed components. The demographic section presented standard queries. The teaching section sought information on educational background, years of experience, area of expertise, and experience in leading ISL. The latter variable was binomial: yes or no.

The Teaching Style Survey, developed by Grasha and Reichmann-Hruska in $1996,{ }^{56}$ consists of 40 statements about teaching (e.g. "Activities in this class encourage students to 
develop their own ideas about content issues." or "What I have to say about a topic is important for students to acquire a broader perspective on the issues in that area.") and asks respondents to indicate on a 5 point Likert scale their dis/agreement with each statement. Raw data were scored, per developer methodology, and each subject was categorized into a teaching style type (TST). Cronbach's alpha internal consistency reliability calculated on data in the present study was 0.78 . Unfortunately, an existing tool to measure the educational perspectives of interest in this study was not available. The researchers sought to identify each subject's affinity to these three perspectives: 1) Progressive, 2) Critical, and 3) Professional as typically described in the work of Dewey, Freire, and Reynolds, respectively. A researcher-developed tool was created following a thorough review of the educational literature. ${ }^{51,60-70}$ From this literature multiple statements were created to reflect the three educational perspectives as they might be applied in physical therapy education. The statements were reviewed by both $\mathrm{PhD}$ level faculty in education and physical therapy. Numerous revisions were made to enhance readability, clarity, and congruence to the respective perspectives. A 10-point Likert response scale for rating dis/agreement with each statement was developed. Next, the tool was piloted with eight physical therapy and education faculty members who had experience in theoretical pedagogy. Additional modifications were made. The final Educational Perspective component of the Faculty Survey data collection tool consisted of 10 items representative of each perspective for a total of 30 items. For scoring, a mean response for each of the three theoretical perspectives was calculated for each subject. The perspective with the highest mean was considered that subject's educational perspective type (EPT). Cronbach's alpha internal consistency reliability calculated on data in the present study was 0.77 . Finally, in addition to the educational perspective data, this section of the tool asked subjects to describe their familiarity, on a 10-point Likert scale, with the three educational 
authors whose work ground the perspectives considered in this study, i.e. Dewey, Freire, and Reynolds.

\section{Subjects}

A sample of physical therapy faculty was sought via listservs of the APTA's Education Section (566 members) (personal contact, Listserv manager at www.aptaeducation.org) and the APTA's Health, Policy and Administration Section's Cross Cultural and International Special Interest Group (CCISIG) (250 members) (personal contact, Listserv manager at jahartman@wisc.edu). The Education Listserv was used to target as large a sample of faculty as possible. The CCISIG Listserv was used to target as many physical therapy faculty involved in ISL as possible. This sample was both a sample of convenience and a purposive sample. Accessing subjects via listservs is not a probabilistic sampling technique, but utilizing the Listservs provided a mechanism to reach a geographically diverse subject pool with specific interests (ISL) in an economical, timely, anonymous, and efficient manner. Postings on the Listservs invited participation in the study by providing a link to the Faculty Survey data collection tool on SurveyMonkey ${ }^{\mathrm{TM}}$. Subjects were also asked to share the survey link with other interested PT faculty who may not have been on the Listservs. An informed consent statement was provided on the first page of the on-line survey. It was stated that consent was presumed if a person went on to complete the survey. Faculty status of respondents was assumed, and one of the demographic questions required clarification of rank. These data collection procedures were approved by the University of Rhode Island's Institutional Review Board.

\section{Procedures}

Descriptive statistics were calculated for the study variables: mean and standard deviation for the Likert data; frequency and percentages for categorical data. T-tests were conducted for 
Likert data to examine differences between the two ISL groups. Finally, logistic regression was used to explore faculty characteristics predictive of participation in ISL and the relationship between involvement in ISL and the demographic, TST, and EPT variables.

Results

Two hundred sixty-six subjects responded to the recruitment. Data from 205 subjects provided complete responses and their data were used for analysis. As appropriate, the collected data were either downloaded or entered manually into Excel $2007^{\circledR}$ then entered into IBM SPSS Version $19^{\circledast}$ for statistical analysis. Forty seven (23\%) of respondents indicated they had led ISL experiences and 158 (77\%) indicated they did not have this experience. No attempt was made to determine whether the ISL experiences of the 47 subjects met the criteria of true SL. ${ }^{22}$ Therefore, it is likely that the ISL experiences took a variety of forms. ${ }^{1}$

Descriptive statistics were calculated on all variables for the total sample and for the two ISL experience groups. Tables 1, 2, 3 and 4 provide these statistics for the demographics, TST, EPT, and familiarity with representative authors respectively. These tables also present inferential statistics that were utilized to determine whether there were significant differences between the two ISL experience groups for the Likert data. Faculty who had led ISL experiences were significantly older and had practiced more years than those who had not led ISL experiences. There were no statistical differences between groups for gender and years teaching. Considering the TST data, more than 50\% of all subjects were categorized as Personal Model / Formal Authority / Delegator. Results were similar for each ISL group. Chi-square analysis indicated that there was no significant relationship between involvement in ISL and TST (chisquare $=6.020(\mathrm{p}>.05))$. In terms of educational perspective, subjects were most often categorized as having a Professional perspective. A significant relationship was identified 
between involvement in ISL and EPT $($ chi-square $=12.394(\mathrm{p}<.05)$ ). For the data provided in Tables 2 and 3, and the accompanying chi-square analyses, it is recognized that the small and unequal cell sample sizes are concerning, and by necessity, make these results preliminary. The data for familiarity with key authors were positively skewed, i.e. a high number of subjects reported "no familiarity" with the key authors. For analysis these data, as noted in Table 4, were collapsed into two categories: "no familiarity" and all others. Many subjects reported that they had "no familiarity" with the key authors: Dewey 41\%; Freire 75\%; and Reynolds 76\%.

Finally, in an effort to explore whether it is possible to identify faculty characteristics that might be predictive of participation in ISL, or if there is a relationship between involvement in ISL and demographic, TST, and EPT data, logistic regression was carried out. Gender was used as a grounding factor for this regression and age, TSTs, and EPTs were added in blocks. Although, the regression model did not significantly predict participation in ISL (Nagelkerke R Square $=.165,(\mathrm{p}>.05))$, membership in the Critical perspective group was identified as a significant factor in the regression $(\beta=12.049, \mathrm{p}<.05)$. It is recognized that the unequal ISL group sizes $(n=158$ versus $n=47)$ are a concern and raise the possibility of a Type II error in the logistic regression.

\section{Discussion}

International service-learning has provided a context for exploring physical therapy faculty's teaching styles and educational perspectives, and compare faculty who lead these experiences and those who do not.

The teaching styles ${ }^{56}$ of the subjects predominantly emphasized role modeling, delegation of responsibilities, student autonomy, facilitation of hands-on active learning, and expertise that is exemplified by high standards of performance. It was less common for subjects to have a 
teaching style that relies on the transmission of information to students who wait to learn from them. These findings are consistent with what education should be at the graduate level in general, and are particularly relevant for physical therapy students who will need to be able to function as autonomous health professionals. ${ }^{3}$ This teaching style data can be utilized while mentoring new faculty, exploring the relationship between teaching styles and student outcomes, and as a catalyst for reflection and rich discussion among all faculty about teaching process, educational philosophy, and pedagogy.

The educational perspective type data open an interesting area of inquiry. A slight majority of subjects identified most strongly with the professional perspective. It is interesting to consider why this percentage was not even higher since physical therapy education mandates a focus on producing professionals who have certain competencies, entry-level attributes, and skills for clinical practice, and the influence of the APTA and CAPTE, which strongly support the professional perspective. Even under such stringent educational constraints, $39 \%$ of subjects identified most strongly with the two non-professional perspectives. Physical therapy programs struggle to get the required professional knowledge and skills into their curricula, and the ideas valued by progressive and critical pedagogues may play a secondary role in physical therapist education. Exploring how faculty with progressive and critical perspectives developed and apply these in the classroom could be important in identifying how to bring the strengths of each of these less commonly held perspectives to physical therapy curricula.

Subject familiarity with representative key authors in education was quite limited. These data present an interesting juxtaposition with the educational perspective data just described. These data confirm the anecdote that many physical therapy faculty enter academia without a strong pedagogical foundation, as evidenced by the lack of familiarity with key educational 
authors. There were, however some interesting variation in the data from those who had some familiarity with the key authors. As a group they were most familiar with the work of Dewey; however, subjects' EPT most frequently aligned with the professional ideas of Reynolds. These data suggest that physical therapy faculty are not conversant with educational theories and probably do not use these frameworks to guide or support their growth as educators. Grounding educational practice in theory can improve physical therapy education by providing support, rationale, and evidence for teaching pedagogy. Additionally, consideration of progressive and critical ideas could contribute to curricular processes, and facilitate progress toward the APTA's 2020 Vision. $^{3}$

There were several meaningful differences between faculty who participate in ISL and those who do not. ISL faculty tended to be older and have more years of practice. It may be that older faculty become dissatisfied with classroom teaching alone and participate in ISL as a way to invigorate their own teaching and learning. They may also have more confidence with their teaching, flexibility, and latitude to explore and develop ISL programs than younger faculty. Making assumptions about faculty interest in ISL may not be helpful, because there does not appear to be one 'type' of faculty that participates in ISL. This finding speaks to ISL's robustness. It is an exciting prospect that ISL may be a pedagogy that unites traditionally diverse faculty for collaborative discussion and work. There is potential to open ISL discussions to all faculty, perhaps drawing in faculty who may have viewed ISL as incompatible with their interests and teaching. These are areas for further research.

Both ISL groups were similar in terms of their teaching styles and their educational perspectives. The data show, however, that subjects' familiarity with key authors differed across groups with ISL faculty being more familiar with Reynolds. In spite of the small numbers seen in 
the chi-square analyses, which make those results preliminary, this line of inquiry is intriguing and worthy of further exploration.

In the logistic regression membership in the Critical EPT group was a statistically significant predictor of ISL participation. Speculation offers that the commonality between the critical perspective and ISL is their shared focus on social justice. Faculty valuing critical pedagogy may be drawn to ISL as an opportunity to express that perspective. It is possible that no other outlet for that perspective routinely exists in their teaching. No strong model to predict ISL participation was able to be developed based on the variables in this study. There are three possible explanations: sample size may not have been large enough, the variables chosen may not be the most relevant, or there may not be any difference between the two ISL groups. Of these, the possibility that there are more important factors to be explored is intriguing. These factors might include past travel experience, comfort with travel, family upbringing (service, travel, etc), previous service activity, family responsibilities, financial factors, or religious affiliation.

The findings in this study are relevant to physical therapy professional organizations, physical therapy education program directors, and individual faculty. First, as the APTA looks at global issues in a more directed way, the development of clinicians who are prepared to practice in a more global environment is essential. ${ }^{3}$ Physical therapist education will play a key role in advancing that vision of becoming a more global profession. International service-learning is being used in many educational programs to address these goals. ${ }^{1,50}$ Developing a deeper understanding of ISL and the faculty who lead it is vital.

Second, consideration of the teaching styles and educational perspectives of physical therapy faculty would provide support for decision-making in educational programs and serve as 
an integral link between practice and programmatic missions and philosophies. For example, the cost and value of educational programs are increasingly being scrutinized by students, their parents, and other stakeholders. A typical physical therapy curriculum is made up almost exclusively of required courses, leaving little leeway for the addition of electives or activities that do not address specific objectives and/or criteria. Programs adding ISL opportunities can utilize information related to educational perspectives as a platform for the discussion of issues surrounding inclusion of ISL in curriculum. Most importantly, the data begin to provide a way for programs to consider looking at how faculty teaching styles and/or perspectives connect to desired student learning outcomes such as social activism, moral development, cultural competence, clinical skills, or some combination of these.

Finally, for both ISL and non-ISL faculty, consideration of teaching style and educational perspectives can inform and enhance teaching and professional development by bridging the gap for faculty who have not been formally trained in educational pedagogy. Tying educational theory to teaching provides structure for physical therapy educators to be more thoughtful about teaching and student interactions, and may lead faculty to examine their strengths and weaknesses as they relate to teaching, student outcomes, evaluations, and relationships. Additionally, improved understanding of educational theory and individual affiliation to those theories can help faculty grow professionally and to more effectively utilize instructional strategies that begin to serve broader philosophical, theoretical, and conceptual goals. Knowledge of various theoretical frames can help support the ideas of faculty who want to explore controversial topics and issues. Theory gives legitimacy to, and a framework for, discussion of topics like diversity, equity, poverty, disenfranchisement, privilege, and social 
justice. These topics have always been meant for discussion in higher education but are often only included tangentially in physical therapy education.

\section{Summary}

International service-learning is growing in physical therapy education and there is no reason to expect that this trend will end any time soon. ${ }^{1,50}$ In that context, this study has provided important descriptive information on physical therapy faculty's teaching styles and educational perspectives, and has compared faculty who lead ISL experiences and those who do not. Results can be used in policy development, strategic planning and decision-making, curriculum development, and staffing and budget decisions. It can serve as an inspiration for the field of physical therapy to open a dialogue about faculty practice and teaching, and encourage faculty to reflect on their teaching practices. Finally, the results can inform, and provide rationale and support for existing and future ISL programs. 


\section{REFERENCES}

1. Pechak $\mathrm{C}$, Thompson $\mathrm{M}$. International service-learning and other international volunteer service opportunities in physical therapist education programs in the USA and Canada. $J$ Phys Ther Educ. 2009;23(1):71-79.

2. Koplan JP, Bond TC, Merson MH, Reddy KS, Rodriguez MH, Sewankambo NK, Wasserheit JN. Towards a common definition of global health. Lancet. 2009;373:1993-1995.

3. American Physical Therapy Association. APTA Vision Statement for Physical Therapy. House of Delegates P06-00-24-35. American Physical Therapy Association Website. http://www.apta.org/AM/Template.cfm?Section=Policies_and_Bylaws\&Template=/CM/HTML Display.cfm\&ContentID=25855. Accessed October 4, 2010.

4. Seifer SD. Service-learning: Community-campus partnerships for health professions education. Acad Med. 1998;73:273-277.

5. Bringle RG, Hatcher JA. A service-learning curriculum for faculty. Mich J Community Serv Learning. 1995;2:33-42.

6. Hofer BK, Pintrich PR. The development of epistemological theories: Beliefs about knowledge and knowing and their relation to learning. Rev Educ Res. 1997;67(1):88-140.

7. Kohlberg L, Mayer R. Development as the aim of education. Harvard Educ Rev. 1972;42: 449-496.

8. Kahne J, Westheimer J. In service of what? The politics of service learning. Phi Delta Kappan. 1996;77:593-599.

9. Lewis A, Smith D. Defining higher order thinking. Theor Pract. 1993;32(3):131-137.

10. Underbakke M, Borg JM, Peterson D. Researching and developing the knowledge base for teaching higher order thinking. Theor Pract. 1993;32(3):147-153.

11. Tishman S, Jay E, Perkins DN. Teaching thinking dispositions: From transmission to enculturation. Theor Pract. 1993;32(3):147-153.

12. Hatcher JA, Bringle RG. Reflection: Bridging the gap between service and learning. Coll Teach. 1997;45(4):153-158.

13. Ash SL, Clayton PH, Atkinson MP. Integrating reflection and assessment to capture and improve student learning. Mich J Community Serv Learning. 2005;11(2):49-60.

14. Hatcher JA, Bringle RG, Muthiah R. Designing effective reflection: What matters to servicelearning? Mich J Community Serv Learning. 2004;11(1):38-46. 
15. Fenzel LM, Peyrot M. Comparing college community participation and future service behaviors and attitudes. Mich J Community Serv Learning. 2005;12(1):23-31.

16. Kiely R, Nielson D. International service learning: The importance of partnerships. Community Coll J. 2003:39-41.

17. Myers-Lipton SJ. Effect of service-learning on college students' attitudes toward international understanding. J Coll Student Dev. 1996;37:659-668.

18. Parker B, Dautoff DA. Service-learning and study abroad: Synergistic learning opportunities. Mich J Community Serv Learning. 2007;13(2):40-53.

19. Porter M, Monard K. Ayni in the global village: Building relationships of reciprocity through international service-learning. Mich J Community Serv Learning. 2001;8(1):5-17.

20. Riner ME, Becklenberg A. Partnering with a sister city organization for an international service-learning experience. J Transcultural Nurs. 2001;12:234-240.

21. Silcox HC, Sweeney S. A people-to-people environmental program in Russia: Experiential service learning in Novgorod, Russia. J Experiential Educ. 1993;16(1):25-27.

22. Williams D, Eiserman WD. Expanding the dialogue: Service learning in Costa Rica and Indonesia. Mich J Community Serv Learning. 1997:4:90-97.

23. Cooks L, Scharrer E. Assessing learning in community service learning: A social approach. Mich J Community Serv Learning. 2006;13(2):44-55.

24. Eyler J, Giles DE, Braxton J. The impact of service-learning on college students. Mich J Community Serv Learning. 1997;4:5-15.

25. Brody SM, Wright SC. Expanding the self through service-learning. Mich J Community Serv Learning. 2004;11(1):14-24.

26. Kendrick JR. Outcomes of service-learning in an introduction to sociology course. Mich J Community Serv Learning. 1996;3:72-81.

27. Lowrey D, May DL, Duchane KA, Coulter-Kern R, De' Bryant, Morris PV, Pomery JG, Bellner M. A logic model of service-learning: Tensions and issues for further consideration. Mich J Community Serv Learning. 2006;12(2):47-60.

28. Driscoll A, Holland B, Gelmon S, Kerrigan S. An assessment model for service-learning: Comprehensive case studies of impact on faculty, students, community, and institution. Mich J Community Serv Learning. 1996;3:66-71.

29. Miller J. The impact of service-learning experiences on students' sense of power. Mich J Community Serv Learning. 1997;4:16-21. 
30. Miller J. Linking traditional and service-learning courses: Outcome evaluations utilizing two pedagological distinct models. Mich J Community Serv Learning. 1994;1(1):29-36.

31. Beling J. Impact of service learning on physical therapist students' knowledge of attitudes toward older adults and on their critical thinking ability. J Phys Ther Educ. 2004;18(1):13-21.

32. Goulet C, Owen-Smith P. Cognitive-affective learning in physical therapy education: From implicit to explicit. J Phys Ther Educ. 2005;19(3):67-72.

33. Ganley KJ, Mueller K. Clinically relevant outcomes of immersion in a community service based experience for physical therapy students. Pediatr Phys Ther. 2006;18(1):90-101.

34. Hoppes S, Bender D, Degrace BW. Service learning is a perfect fit for occupational and physical therapy education. J Allied Health. 2005;34(1):47-50.

35. Reicherter FA, Manual Williams B. Service learning in physical therapy: Enhancing healthy lifestyles of older African American adults in Washington, DC. Creative Coll Teach J. 2005; 2(1):65-77.

36. Village D, Clouten N, Millar AL, Geigle A, Okafor N, Simuel D, Uzarraga A. Comparison of the use of service learning, volunteer, and pro bono activities in physical therapy curricula. $J$ Phys Ther Educ. 2004;18(1):22-28.

37. Reynolds PJ. How service-learning experiences benefit physical therapist students' professional development: a grounded theory study. J Phys Ther Educ. 2005;19(1):41-51.

38. Hammond C. Integrating service and academic study: Faculty motivation and satisfaction in Michigan higher education. Mich J Community Serv Learning. 1994;1(1):21-28.

39. Braskamp LA. Developing global citizens. J Coll and Char. 2008; 10(1):1-7.

40. O’Meara K, Niehaus E. Service-learning is... How faculty explain their practice. Mich J Community Serv Learning. 2009;16(1):17-32.

41. Abes ES, Jackson G, Jones SR. Factors that motivate and deter faculty use of servicelearning. Mich J Community Serv Learning. 2002;9(1):5-17.

42. Banerjee M, Hausafus CO. Faculty use of service-learning: Perceptions, motivations, and impediments for the human sciences. Mich J Community Serv Learning. 2007;14(1):32-45.

43. Driscoll A. Studying faculty and service-learning: Directions for inquiry and development. Mich J Community Serv Learning. Special Issue: Strategic Directions for Service-Learning Research. 2000:35-41. 
44. Harwood AM, Ochs L, Currier D, Duke S, Hammond J, Moulds L, Stout K, Werder C. Communities for growth: Cultivating and sustaining service-learning teaching and scholarship in a faculty fellows program. Mich J Community Serv Learning. 2005;12(1):41-51.

45. Hesser G. Faculty assessment of student learning: Outcomes attributed to service-learning and evidence of changes in faculty attitudes about experiential education. Mich J Community Serv Learning. 1995;2:33-42.

46. Levine MA. Seven steps to getting faculty involved in service-learning: How a traditional faculty member came to teach a course on "Voluntarism, Community, and Citizenship." Mich J Community Serv Learning. 1994;1(1):110-114.

47. McKay VC, Rozee PD. Characteristics of faculty who adopt community service learning pedagogy. Mich J Community Serv Learning. 2004;10(2):21-33.

48. Pribbenow DA. The impact of service-learning pedagogy on faculty teaching and learning. Mich J Community Serv Learning. 2005;11(2):25-38.

49. Dockter MK. An International Service-Learning Experience for Physical Therapy Students: Its Meaning and Effect on Civic Engagement and Leadership Skills. [dissertation]. Grand Forks, ND: University of North Dakota; 2004.

50. Pechak C, Thompson M. Going global in physical therapist education: International servicelearning in US-based programs. Physiother Res Int. December 2010.

51. Deans T. Service-learning in two keys: Paulo Freire's critical pedagogy in relation to John Dewey's pragmatism. Mich J Community Serv Learning. 1999;6:15-29.

52. Spake E, Salem A. Setting the stage: The scholarship of teaching and learning. J Phys Ther Educ. 2005;19(3):5-13.

53. Silver HS, Hanson JR, Strong RW, Schwartz, PB. Teaching styles and strategies. Woodbridge, NJ; Thoughtful Education Press; 1996.

54. The 4MAT® Teaching Style Inventory (TSI). Accessed 12/18/08 at http://www.aboutlearning.com/index.php/learning-assessments/teaching-styles-inventory

55. CORD (C (2007). Teaching styles inventory. Accessed 12/18/08 at http://www.texascollaborative.org/TSI.htm

56. Grasha AF, Reichmann-Hruska S. Teaching style survey. Cincinnati, OH: University of Cincinnati; 1996.

57. Grasha AF. A matter of style: The teacher as expert, formal authority, personal model, facilitator, and delegator. Coll Teach. 1994;42(4):142-49. 
58. Grasha AF. A special section: Discovering your best teaching style. Coll Teach. 1994;42(4):122-124.

59. Grasha AF. Teaching with style; A practical guide to enhancing learning by understanding teaching and learning styles. Pittsburgh, PA: Alliance Publishers: 1996.

60. Giles DE, Eyler J. The theoretical roots of service-learning in John Dewey: Toward a theory of service-learning. Mich J Community Serv Learning. 1994;1(1):77-85.

61. Hatcher JA. The moral dimensions of John Dewey's philosophy: Implications for undergraduate education. Mich J Community Serv Learning. 1997;4:22-29.

62. Dewey J. Democracy and Education. An Introduction to the Philosophy of Education. 1966 ed. New York, NY: Free Press; 1916.

63. Dewey J. How We Think. A Restatement of the Relation of Reflective Thinking to the Educative Process. Revised ed. Boston: D. C. Heath; 1933.

64. Dewey J. Experience and Education. New York, NY: Collier Books; 1938.

65. Freire P. Pedagogy of the oppressed, $20^{\text {th }}$ Anniversary Ed. New York: Continuum: 1993.

66. Kolb DA. Experiential learning: Experiences as a source of learning and development. Englewood Cliffs, NJ: Prentice Hall; 1984.

67. Piaget J. Cognitive development in children: Development and learning. J Res Sci Teach. 1964; 40:S8-S18.

68. Vygotsky L. Mind in society: The development of higher psychological processes. Cambridge, MA: Harvard University Press; 1968.

69. Simon D. ed. Fifty key thinkers on development. New York, NY: Routledge Publishing; 2006.

70. Giroux H. Lessons from Paulo Freire. Chronicle of Higher Education Web site. http://chronicle.com/article/Lessons-From-Paulo-Freire/124910/. Accessed December 12, 2010. 
Table 1. Descriptive Statistics for Demographic Variables

\begin{tabular}{|c|c|c|c|}
\hline Item & $\begin{array}{l}\text { Total Sample } n(\%) \\
\qquad(n=205)\end{array}$ & $\begin{array}{c}\text { N-ISL n (\%) } \\
(n=158)\end{array}$ & $\begin{array}{l}\text { Y-ISL n (\%) } \\
\quad(n=47)\end{array}$ \\
\hline \multirow[t]{6}{*}{ Gender } & Female $154(77.4 \%)$ & Female $115(74.7 \%)$ & Female $39(86.7 \%)$ \\
\hline & Male $45(22.6 \%)$ & Male $39(25.3 \%)$ & Male $6(13.3 \%)$ \\
\hline & $\mathrm{n}=199$ & $\mathrm{n}=154$ & $\mathrm{n}=45$ \\
\hline & Missing data $=6$ & Missing data $=4$ & Missing data $=2$ \\
\hline & Total 205 & Total 158 & Total 47 \\
\hline & & \multicolumn{2}{|c|}{ Pearson chi-square $=.091 \mathrm{NS}$} \\
\hline \multirow[t]{5}{*}{ Age (years) } & $\begin{array}{l}\text { Mean }=49.92 \\
\quad(+/-8.03)\end{array}$ & $\begin{array}{c}\text { Mean }=48.98 \\
(+/-7.71)\end{array}$ & $\begin{array}{c}\text { Mean }=53.12 \\
(+/-8.49)\end{array}$ \\
\hline & $\mathrm{n}=150$ & $\mathrm{n}=117$ & $\mathrm{n}=32$ \\
\hline & Missing 55 & Missing 40 & Missing 15 \\
\hline & Total 205 & Total 158 & Total 47 \\
\hline & & \multicolumn{2}{|c|}{$\mathrm{t}=2.610, \mathrm{p}=.010^{*}$} \\
\hline \multirow[t]{5}{*}{ Years as PT } & $\begin{array}{l}\text { Mean }=26.23 \\
\quad(+/-9.45)\end{array}$ & $\begin{array}{l}\text { Mean }=25.36 \\
(+/-9.20)\end{array}$ & $\begin{array}{c}\text { Mean }=29.02 \\
(+/-9.86)\end{array}$ \\
\hline & $\mathrm{n}=197$ & $\mathrm{n}=152$ & $\mathrm{n}=45$ \\
\hline & Missing 8 & Missing 6 & Missing 2 \\
\hline & Total 205 & Total 158 & Total 47 \\
\hline & & \multicolumn{2}{|c|}{$\mathrm{t}=2.194, \mathrm{p}=.029^{*}$} \\
\hline \multirow[t]{5}{*}{$\begin{array}{l}\text { Years } \\
\text { Teaching }\end{array}$} & $\begin{array}{c}\text { Mean }=14.46 \\
(+/-8.58)\end{array}$ & $\begin{array}{c}\text { Mean = 13.98 } \\
(+/-8.08)\end{array}$ & $\begin{array}{c}\text { Mean = 16.02 } \\
(+/-10.06)\end{array}$ \\
\hline & $\mathrm{n}=203$ & $\mathrm{n}=157$ & $\mathrm{n}=46$ \\
\hline & Missing 2 & Missing 1 & Missing 1 \\
\hline & Total 205 & Total 158 & Total 47 \\
\hline & & \multicolumn{2}{|c|}{$\mathrm{t}=1.435, \mathrm{p}=.153 \mathrm{NS}$} \\
\hline
\end{tabular}


Table 2. Descriptive Statistics for Teaching Style Type

\begin{tabular}{|l|c|c|c|}
\hline Item & $\begin{array}{c}\text { Sample n (\%) } \\
(\mathrm{n}=205)\end{array}$ & $\begin{array}{c}\text { N-ISL n (\%) } \\
(\mathrm{n}=158)\end{array}$ & $\begin{array}{c}\text { Y-ISL n (\%) } \\
(\mathrm{n}=47)\end{array}$ \\
\hline $\begin{array}{l}\text { Type 1 } \\
\text { Expert / Formal Authority }\end{array}$ & $\begin{array}{c}19 \\
(9.3 \%)\end{array}$ & $\begin{array}{c}14 \\
(8.9 \%)\end{array}$ & $\begin{array}{c}5 \\
(10.6 \%)\end{array}$ \\
\hline $\begin{array}{l}\text { Type 2 } \\
\text { Personal Model / Formal Authority }\end{array}$ & $\begin{array}{c}(51.2 \%) \\
\text { / Delegator }\end{array}$ & $\begin{array}{c}87 \\
(55.1 \%)\end{array}$ & $(42.6 \%)$ \\
\hline $\begin{array}{l}\text { Type 3 } \\
\text { Formal Authority / Delegator }\end{array}$ & 24 & 17 & 7 \\
\hline $\begin{array}{l}\text { Type 4 } \\
\text { Formal Authority / Facilitator / }\end{array}$ & $(11.7 \%)$ & $(10.8 \%)$ & $(14.9 \%)$ \\
Delegator & 42 & 28 & 14 \\
\hline Type 5 & $13 \%)$ & $(17.7 \%)$ & $(29.8 \%)$ \\
Delegator / Facilitator & $(6.3 \%)$ & $(7.6 \%)$ & $(0.02 \%)$ \\
\hline $\mathrm{n}$ & 205 & 158 & 47 \\
\hline
\end{tabular}

Chi-square $=6.020(\mathrm{p}>.05)$ 
Table 3. Descriptive Statistics for Educational Perspective Type

\begin{tabular}{|l|c|c|c|}
\hline Item & $\begin{array}{c}\text { Sample n (\%) } \\
(\mathrm{n}=205)\end{array}$ & $\begin{array}{c}\text { N-ISL n (\%) } \\
(\mathrm{n}=158)\end{array}$ & $\begin{array}{c}\text { Y-ISL n (\%) } \\
(\mathrm{n}=47)\end{array}$ \\
\hline Progressive & $\begin{array}{c}80 \\
(39.0 \%)\end{array}$ & $\begin{array}{c}60 \\
(38.0 \%)\end{array}$ & $\begin{array}{c}20 \\
(42.6 \%)\end{array}$ \\
\hline Critical & 5 & 1 & 4 \\
$(0.6 \%)$ & $(8.5 \%)$ \\
\hline Professional & $\begin{array}{c}5.4 \%) \\
(54.2 \%)\end{array}$ & $\begin{array}{c}88 \\
(55.7 \%)\end{array}$ & $\begin{array}{c}23 \\
(48.9 \%)\end{array}$ \\
\hline No clear Perspective Type & 9 & 9 & 0 \\
& $(4.4 \%)$ & $(5.7 \%)$ & $(0 \%)$ \\
\hline $\mathrm{n}$ & 205 & 158 & 47 \\
\hline
\end{tabular}

Chi-square $=12.394(\mathrm{p}<.05)$ 
Table 4. Descriptive Statistics for Familiarity* with Key Authors Variable: Collapsed Categories

\begin{tabular}{|c|c|c|c|c|}
\hline Item & \multicolumn{2}{|c|}{ Sample } & \multirow[t]{2}{*}{ N-ISL } & \multirow[t]{2}{*}{ Y-ISL } \\
\hline $\begin{array}{c}\text { Likert Scale } \\
\text { Score }\end{array}$ & 1 & $2-10$ & & \\
\hline \multirow[t]{3}{*}{ Dewey } & $(n=85)$ & $(\mathrm{n}=120)$ & $(n=84)$ & $(n=36)$ \\
\hline & Mean $=1.00$ & Mean $=6.48$ & Mean $=6.50$ & Mean $=6.44$ \\
\hline & & & \multicolumn{2}{|c|}{$\mathrm{t}=.112, \mathrm{p}=.911 \mathrm{NS}$} \\
\hline \multirow[t]{3}{*}{ Freire } & $(\mathrm{n}=154)$ & $(\mathrm{n}=51)$ & $(\mathrm{n}=32)$ & $(n=19)$ \\
\hline & Mean $=1.00$ & Mean $=6.61$ & Mean $=6.63$ & Mean $=6.58$ \\
\hline & & & \multicolumn{2}{|c|}{$\mathrm{t}=.063, \mathrm{p}=.950 \mathrm{NS}$} \\
\hline \multirow[t]{3}{*}{ Reynolds } & $(\mathrm{n}=155)$ & $(n=50)$ & $(\mathrm{n}=34)$ & $(n=16)$ \\
\hline & Mean $=1.00$ & Mean $=6.08$ & Mean $=5.35$ & Mean $=7.63$ \\
\hline & & & \multicolumn{2}{|c|}{$\mathrm{t}=2.769, \mathrm{p}=.008^{* *}$} \\
\hline
\end{tabular}


Appendix A

Teaching Style Type Descriptions

\begin{tabular}{|c|c|}
\hline Type & Description \\
\hline Expert & $\begin{array}{l}\text { Teacher: } \\
\text { Transmits information and detailed, expert knowledge } \\
\text { Displays and strives to maintain expert status among students } \\
\text { Challenges students to enhance competence } \\
\text { Advantage: } \\
\text { Teacher is seen to possess information, knowledge, and skills } \\
\text { Disadvantage: } \\
\text { Overt display of knowledge can be intimidating } \\
\text { Underlying thought processes may not be clear to learners }\end{array}$ \\
\hline $\begin{array}{l}\text { Formal } \\
\text { Authority }\end{array}$ & $\begin{array}{l}\text { Teacher: } \\
\text { Concerned with correct, acceptable, standard-based performance } \\
\text { Possesses status among students by virtue of knowledge and role } \\
\text { Cares about providing positive and negative feedback, establishing learning } \\
\text { goals, expectations, and rules of conduct } \\
\text { Advantage: } \\
\text { Focus on clear expectations and acceptable ways of doing things } \\
\text { Disadvantage: } \\
\quad \text { Can lead to rigid, standardized ways of managing students and concerns }\end{array}$ \\
\hline $\begin{array}{l}\text { Personal } \\
\text { Model }\end{array}$ & $\begin{array}{l}\text { Teacher: } \\
\text { Uses illustrations and direct / personal examples } \\
\text { Establishes a prototype for how to think and behave } \\
\text { Encourages students to observe and emulate instructor's approach } \\
\text { Oversees, guides, and directs } \\
\text { Advantage: } \\
\text { Hands-on with emphasis on direct observation } \\
\text { Disadvantage: } \\
\text { Teachers may believe their approach is best way } \\
\text { Students may feel inadequate if they cannot live up to expectations }\end{array}$ \\
\hline Facilitator & $\begin{array}{l}\text { Teacher: } \\
\text { Guides and directs by asking questions, exploring options, and suggesting } \\
\text { alternatives } \\
\text { Emphasizes personal nature of teacher-student interactions } \\
\text { Prioritizes the development of students' capacity for independent action and } \\
\text { responsibility } \\
\text { Consults and provides support and encouragement } \\
\text { Advantage: } \\
\text { Flexibility } \\
\text { Focus on students' needs and goals } \\
\text { Disadvantage: } \\
\text { Time consuming } \\
\text { Ineffective when a more direct approach is needed }\end{array}$ \\
\hline
\end{tabular}




\begin{tabular}{|l|l|}
\hline Delegator & $\begin{array}{l}\text { Teacher: } \\
\text { Focuses on developing students' independence and ability to function } \\
\text { autonomously }\end{array}$ \\
Acts as a resource person \\
Advantage: \\
Contributes to students' perceptions of themselves as independent learners \\
Disadvantage: \\
Teacher may misread students' readiness to work independently \\
Students may become anxious when given autonomy
\end{tabular}

